\title{
TINGKAT PENGETAHUAN IBU TENTANG PERAWATAN KULIT PADA BAYI DAN BALITA DI DESA GONILAN
}

\author{
Mother's Knowledge Regarding Baby's Skin Maintenance In Gonilan Suburb
}

\author{
Ajeng Novita Sari ${ }^{1}$, Lilik Hanifah ${ }^{2}$ \\ ${ }^{1}$ Politeknik Santo Paulus Surakarta, \\ ${ }^{2}$ STIKES Mamba'ul 'Ulum Surakarta \\ ajengnovitasari@yahoo.co.id
}

\begin{abstract}
ABSTRAK
Latar Belakang : Berbagai macam penyakit kulit saat ini masih menjadi masalah kesehatan bagi masyarakat di dunia, tak terkecuali di Indonesia. Masalah kulit pada anak sangat beragam penyebabnya. Pengetahuan orangtua terutama ibu sangat erat kaitannya dengan pendidikan, sehingga akan mempengaruhi perilaku orangtua dalam menjaga kesehatan kulit pada anaknya.

Tujuan : Penelitian ini bertujuan untuk mengetahui tingkat pengetahuan ibu tentang perawatan kulit pada bayi dan balita RW VIII Desa Gonilan Pada Tahun 2020.

Metode : Penelitian ini menggunakan metode deskriptif dengan pendekatan cross sectional. Populasi dalam penelitian ini adalah ibu yang mempunyai bayi dan balita di RW VIII Desa Gonilan Kecamatan Kartasura Kabupaten Sukoharjo Tahun 2020 sebanyak 46 responden. Teknik sampling yang digunakan adalah Accidental Sampling dimana saat penelitian dijumpai responden sebanyak $30 \mathrm{ibu}$ yang memiliki bayi dan balita. Alat pengumpulan data menggunakan kuesioner. Analisis data menggunakan jenis distribusi frekuensi.

Hasil penelitian : penelitian dari tingkat pengetahuan ibu tentang perawatan kulit pada bayi dan balita mayoritas memiliki tingkat pengetahuan cukup yaitu sebanyak 19 orang $(63,33 \%)$. Berdasarkan karakteristik umur responden mayoritas pada umur 23-29 tahun yaitu sebanyak 11 orang (36,67\%), berdasarkan karakteristik pendidikan mayoritas responden berpendidikan SMP yaitu sebanyak 10 orang $(33,33 \%)$, berdasarkan karakteristik pekerjaan responden mayoritas responden tidak bekerja yaitu sebanyak 16 orang $(53,33 \%)$ berdasarkan karakteristik jumlah anak responden mayoritas jumlah anak 2 yaitu sebanyak 14 orang $(46,67 \%)$.

Simpulan : Di desa Gonilan Kecamatan Kartasura Kabupaten Sukoharjo pada Tahun 2020 tingkat pengetahuan ibu tentang perawatan kulit pada bayi dan balita memiliki pengetahuan dengan kategori cukup $(63,33 \%)$.
\end{abstract}

Kata kunci : Tingkat pengetahuan, Ibu, Perawatan kulit pada bayi dan balita. 


\begin{abstract}
Background: Skin diseases are still become a serious concern for people in the world, including Indonesia. Skin problems in children derived from many causes. Parent's knowledge particularly mother is linked to education background. Thus, may affect the parents' behavior on caring of their children' healthy skin. This study aim to investigate the mother's knowledge regarding to the skin maintenance of baby and toddler in Gonilan suburban in 2020.

Method: this study used descriptive method with cross-sectional design. The population targetted are 46 mothers who have baby and toddler in Gonilan suburb, Kartasura district, Region of Sukoharjo in 2020. The sampling technique used was Accidental Sampling, where at the time of the research, 30 mothers who had babies and toddlers were found. The data collection tool uses a questionnaire. Data analysis uses a type of frequency distribution.

Result: the majority of mother's knowledge about baby's skin maintenance is sufficient that is 19 subjects (63.33\%). While according to the age, most of subjects are in the age 23 - 29 years old that is 11 respondents (36.67\%). Further, the characteristic of education background showed that junior high school are the main feature where 10 people involved (33.33\%). Apparently, 16 subjects (53.33\%) are housewifes and does not work. Additionally, based on the number of children, the majority of respondents or 14 people involved (46,67\%) has 2 children.
\end{abstract}

Conclusion: the level of mother's knowledge in Gonilan suburb regarding skin maintenance on baby and toddler in February 2020 is sufficient (63.33\%).

Keywords: level of knowledge, mother, skin maintenance on baby and toddler.

\title{
PENDAHULUAN
}

Penyakit kulit semakin banyak berkembang, hal ini dibuktikan dari profil kesehatan Indonesia tahun 2015 yang menunjukkan bahwa penyakit kulit dan jaringan subkutan menjadi peringkat ketiga dari 10 penyakit terbanyak pada pasien rawat jalan di rumah sakit se-Indonesia berdasarkan jumlah kunjungan yaitu sebanyak 192.414 kunjungan, kunjungan kasus baru 122.076 kunjungan sedangkan kasus lama 70.338 kunjungan (Kemenkes RI, 2016).

Kejadian dermatitis di Amerika Serikat, Eropa, Jepang, Australia, dan negara Industri lain memiliki prevalensi dermatitis atopik 10 sampai $20 \%$ pada anak dan 1-3\% terjadi pada orang dewasa. Sedangkan di Negara Agraris misalnya China, Eropa Timur, Asia Tengah memiliki prevalensi Dermatitis Atopik lebih rendah. Berdasarkan data gambaran kasus penyakit kulit dan subkutan lainnya merupakan peringkat ketiga dari sepuluh penyakit utama dengan $86 \%$ adalah dermatitis diantara 192.414 kasus penyakit kulit di beberapa Rumah Sakit Umum di Indonesia tahun 2011 (Hegab, D.S, 2015).

Dermatitis atopik terjadi pada segala usia, sekitar $15-30 \%$ pada 1,3 anakanak dan $1-2 \%$ pada dewasa. Dermatitis atopik dimulai pada bayi (45\% kasus 
dimulai di usia 6 bulan) dan $70 \%$ kasus sebelum usia 5 tahun. Prevalensi kasus Dermatitis atopik pada anak meningkat di berbagai negara terutama negara barat. Satu penelitian menyatakan prevalensi Dermatitis atopik pada anak usia 6-7 tahun dalam waktu satu tahun di Iran dan Cina sekitar 2\%, tetapi di Australia, Inggris, dan Skandinavia sekitar 20\% (Staab, D,et all, 2015)

Prevalensi penyakit dermatitis atopik didapatkan meningkat setiap tahunnya di Indonesia, didapatkan rekapitulasi yang telah dilakukan oleh Kelompok Studi Dermatologi Anak (KSDAI) dari lima kota besar di Indonesia, didapatkan dari 10 besar penyakit kulit anak dan dari sepuluh rumah sakit besar yang tersebar di seluruh Indonesia, dermatitis atopik telah menempati peringkat pertama sebesar 23,7\% dan pada tahun 2010 kejadian dermatitis telah mencapai 36\% angka kejadian (Nurfadilah S,dkk, 2014).

Memiliki anak yang sehat merupakan dambaan setiap orang tua. Modal utama untuk mewujudkannya adalah menerapkan pola hidup sehat sedini mungkin. Langkah awal yang dapat dilakukan adalah dengan merawat anak sesuai dengan tahap-tahap tumbuh kembanganya. Perawatan tersebut dilakukan untuk menghindari dan mencegah timbulnya penyakit yang mungkin terjadi yang salah satunya adalah masalah kulit. Orang tua harus tau bahwa kulit bayi sangat sensitif, berbeda dari kulit orang dewasa, kulit bayi lebih tipis dan halus. Itu sebabnya kulit bayi lebih peka dan mudah terjadi gangguan kulit (Sudilarsih, 2010).

Semua bayi memiliki kulit yang sangat peka, berbeda dengan kulit orang dewasa yang tebal dan mantap, kondisi kulit pada bayi yang relatif tipis menyebabkan bayi lebih rentan terhadap infeksi, iritasi, dan alergi. Secara struktural, kulit bayi dan balita belum berkembang dan berfungsi secara optimal, sehingga diperlukan perawatan yang lebih menekankan pada perawatan kulit, sehingga bisa meningkatkan fungsi utama kulit sebagai pelindung dari pengaruh luar tubuh (Manulang, 2010).

Pengetahuan orangtua terutama ibu sangat erat kaitannya dengan pendidikan, sehingga akan mempengaruhi perilaku orangtua dalam menjaga kesehatan kulit pada anaknya. Menurut hasil penelitian Ansori pada tahun 2010, pendidikan ibu yang tinggi dapat memudahkan ibu dalam memahami informasi yang disampaikan. Sedangkan pendidikan ibu yang rendah mengakibatkan kesulitan ibu dalam menerima dan memahami informasi yang disampaikan. Dan kurangnya pengetahuan ibu mengenai perawatan kulit pada bayi mengakibatkan kesalahan dalam merawat kulit (Luvilla B dkk, 2019).

Pengetahuan ibu diperlukan untuk merawat kulit bayi sehari-hari, misalnya seperti: memandikan secara teratur, mengganti popok atau baju pada saat yang tepat, memilih bahan pakaian yang lembut, memilih kosmetik berupa sabun mandi, sampo dan minyak khusus bayi dipilih dengan tepat dan disesuaikan dengan keadaan kulit bayi (Nurhayati dan Maryam, 2013).

Survey pendahuluan yang dilakukan di RW VIII Desa Gonilan Kecamatan Kartasura Kabupaten Sukoharjo terdapat $60 \%$ ibu yang memiliki bayi dan balita belum memahami tentang pentingnya perawatan kulit bayi dan balita akibat gigitan serangga, biang keringat serta kebersihan lingkungan. Berdasarkan uraian 
tersebut, maka peneliti tertarik untuk melakukan penelitian mengenai Tingkat Pengetahuan Ibu Tentang Perawatan Kulit Pada Bayi dan Balita Di Desa Gonilan.

\section{METODE PENELITIAN}

Jenis penelitian ini adalah deskriptif dengan pendekatan cross sectional. Alat pengumpulan data menggunakan kuesioner. Populasi dalam penelitian ini adalah seluruh ibu yang memiliki bayi dan balita di Kelurahan Gonilan RW. VIII yang berjumlah 46 orang. Teknik pengambilan sampel menggunakan teknik accidental sampling sehingga diperoleh 30 orang ibu yang memiliki bayi dan balita. Instrumen dalam penelitian ini menggunakan kuesioner yang terlebih dahulu dilakukan uji validitas dengan menggunakan rumus person product momment. Setelah dilakukan uji validitas diperoleh hasil dari 30 item pertanyaan yang dinyatakan valid adalah $0,462-0,694>\mathrm{r}$ tabel 0,444 pada taraf signifikansi $5 \%$ dengan jumlah responden 20. Setelah dilakukan uji reliabilitas diketahui tingkat reliabilitas instrumen yang digunakan dengan kategori reliabel $r$ hitung yang didapatkan yaitu 0,925 . Sedangkan $r$ tabel dengan responden 20 orang taraf signifikansi $5 \%$ adalah 0,444. Dengan demikian dapat disimpulkan bahwa instrumen yang digunakan terbukti reliabel. Metode pengumpulan data menggunakan data primer dan data sekunder. Pengambilan data primer dilakukan dengan membagikan kuesioner kepada responden, sebelum mengisi kuesioner responden diberi penjelasan tentang cara mengisi kuesioner dan selanjutnya memberikan informed consent yang diikuti penyerahan kuesioner. Setelah kuesioner diterima oleh responden, responden langsung mengisi kuesioner yang diberikan sesuai dengan ketentuan yang ada. Selanjutnya kuesioner dikumpulkan oleh peneliti untuk diperiksa kelengkapan jawaban, bila kurang lengkap dikembalikan pada responden untuk dilengkapi. Data sekunder berupa daftar nama, ibu bayi dan balita pada bulan Februari tahun 2020. Teknik pengolahan data dalam penelitian ini adalah editing, codding sheet, data entry, dan tabulating. Analisa data dalam penelitian ini menggunakan distribusi frekuensi.

\section{HASIL DAN PEMBAHASAN}

\section{Hasil}

Tabel 1 Distribusi Frekuensi Variabel Pengetahuan Ibu Tentang Perawatan Kulit Pada Bayi dan Balita

\begin{tabular}{ccc}
\hline Tingkat Pengetahuan & Frekuensi (f) & Prosentase (\%) \\
\hline Baik & 5 & 16,67 \\
Cukup & 19 & 63,33 \\
Kurang & 6 & 20 \\
Jumlah & 30 & 100 \\
\hline
\end{tabular}

Berdasarkan tabel di atas dapat dilihat bahwa pengetahuan ibu tentang perawatan kulit pada bayi dan balita di RW VIII Desa Gonilan Kecamatan 
Kartasura Kabupaten Sukoharjo tahun 2020 adalah baik sebanyak 5 responden $(16,67 \%)$, cukup sebanyak 19 responden $(63,33 \%)$ dan kurang sebanyak 6 responden $(20 \%)$.

Tabel 2 Distribusi Frekuensi Pengetahuan Ibu Tentang Perawatan Kulit Pada Bayi dan Balita Berdasarkan Karakteristik Umur

\begin{tabular}{|c|c|c|c|c|c|c|c|c|}
\hline \multirow{3}{*}{$\begin{array}{l}\text { Umur } \\
\text { (Tahun) }\end{array}$} & \multicolumn{8}{|c|}{ Tingkat Pengetahuan } \\
\hline & \multicolumn{2}{|c|}{ Baik } & \multicolumn{2}{|c|}{ Cukup } & \multicolumn{2}{|c|}{ Kurang } & \multicolumn{2}{|c|}{ Total } \\
\hline & $f$ & $\%$ & $f$ & $\%$ & $f$ & $\%$ & $f$ & $\%$ \\
\hline $20-24$ & 0 & 0 & 3 & 10 & 1 & 3,33 & 4 & 13,33 \\
\hline $25-29$ & 2 & 6,67 & 8 & 26,67 & 1 & 3,33 & 11 & 36,67 \\
\hline $30-34$ & 2 & 6,67 & 2 & 6,67 & 1 & 3,33 & 5 & 16,67 \\
\hline $35-40$ & 1 & 3,33 & 6 & 20 & 3 & 10 & 10 & 33,33 \\
\hline Jumlah & 5 & 16,67 & 19 & 63,34 & 6 & 19,99 & 30 & 100 \\
\hline
\end{tabular}

Berdasarkan tabel di atas dapat diketahui bahwa umur responden bervariasi mulai dari 20-40 tahun, responden yang berumur 20-24 tahun sebanyak 4 responden $(13,33 \%)$ dengan tingkat pengetahuan cukup 3 responden $(10 \%)$ dan kurang ada 1 responden (3,33\%), umur 25-29 tahun sebanyak 11 responden $(36,67 \%)$ dengan tingkat pengetahuan baik sebanyak 2 responden $(6,67 \%)$, cukup sebanyak 8 responden $(26,67 \%)$ dan kurang ada 1 orang $(3,33 \%)$. Umur $30-34$ tahun sebanyak 5 responden $(16,67 \%)$ dengan tingkat pengetahuan baik dan cukup sebanyak 2 responden $(6,67 \%)$ sedangkan kategori kurang ada 1 responden (3,33\%), umur 35-40 tahun sebanyak 10 responden $(33,33 \%)$ dengan tingkat pengetahuan cukup sebanyak 6 responden (20\%), kurang sebanyak 3 responden (10\%) dan baik ada 1 responden $(3,33 \%)$.

Tabel 3 Distribusi Frekuensi Pengetahuan Ibu Tentang Perawatan Kulit Pada Bayi dan Balita Berdasarkan Karakteristik Pendidikan

\begin{tabular}{lcccccccc}
\hline \multirow{2}{*}{\multicolumn{1}{c}{ Pendidikan }} & \multicolumn{9}{c}{ Tingkat Pengetahuan } \\
\cline { 2 - 9 } & \multicolumn{2}{c}{ Baik } & \multicolumn{2}{c}{ Cukup } & \multicolumn{2}{c}{ Kurang } & \multicolumn{2}{c}{ Total } \\
\cline { 2 - 9 } & $f$ & 0 & $f$ & $\%$ & $f$ & $\%$ & $f$ & $\%$ \\
\hline Tidak Tamat SD & 0 & 0 & 2 & 6,67 & 1 & 3,33 & 3 & 10 \\
SD & 1 & 3,33 & 3 & 10 & 4 & 13,33 & 8 & 26,67 \\
SMP & 1 & 3,33 & 8 & 26,67 & 1 & 3,33 & 10 & 33,33 \\
SMA & 2 & 6,67 & 6 & 20 & 0 & 0 & 8 & 26,67 \\
Perguruan Tinggi & 1 & 3,33 & 0 & 0 & 0 & 0 & 1 & 3,33 \\
Jumlah & 5 & 16,66 & 19 & 63,34 & 6 & 19,99 & 30 & 100 \\
\hline
\end{tabular}

Berdasarkan tabel di atas dapat diketahui bahwa pendidikan responden bervariasi, mulai dari tidak tamat SD sampai Perguruan Tinggi. Sebagian besar responden berpendidikan terakhir SMP sebanyak 10 responden $(33,33 \%)$ dengan tingkat pengetahuan cukup sebanyak 8 responden (26,67\%), kurang sebanyak 1 responden $(3,33 \%)$ dan baik ada 1 responden $(3,33 \%)$, SMA sebanyak 8 responden $(26,67 \%)$ dengan tingkat pengetahuan cukup sebanyak 6 responden 
(20\%), baik sebanyak 2 responden $(6,67 \%)$, Tamat SD sebanyak 8 responden (26,67\%) dengan tingkat pengetahuan kurang sebanyak 4 responden $(13,33 \%)$, cukup sebanyak 3 responden $(10 \%)$ dan baik ada 1 responden $(3,33 \%)$. Tidak Tamat SD sebanyak 3 responden (10\%) dengan tingkat pengetahuan cukup sebanyak 2 responden $(6,67 \%)$ dan kurang ada 1 responden $(3,33 \%)$. Perguruan Tinggi ada 1 responden $(3,33 \%)$ dengan tingkat pengetahuan baik.

Tabel 4 Distribusi Frekuensi Variabel Pengetahuan Ibu Tentang Perawatan Kulit Pada Bayi dan Balita Berdasarkan Pekerjaan

\begin{tabular}{lcccccccc}
\hline \multirow{3}{*}{ Pekerjaan } & \multicolumn{9}{c}{ Tingkat Pengetahuan } \\
\cline { 2 - 9 } & \multicolumn{2}{c}{ Baik } & \multicolumn{9}{c}{ Cukup } & \multicolumn{2}{c}{ Kurang } & \multicolumn{2}{c}{ Total } \\
\cline { 2 - 9 } & $f$ & $\%$ & $f$ & $\%$ & $f$ & $\%$ & $f$ & $\%$ \\
\hline Tidak Bekerja & 2 & 6,67 & 12 & 40 & 2 & 6,67 & 16 & 53,34 \\
Bekerja & 3 & 10 & 7 & 23,33 & 4 & 13,33 & 14 & 46,66 \\
Jumlah & 5 & 16,67 & 19 & 63,33 & 6 & 20 & 30 & 100 \\
\hline
\end{tabular}

Berdasarkan tabel di atas dapat diketahui bahwa mayoritas responden adalah tidak bekerja sebanyak 16 responden $(53,34 \%)$ dengan tingkat pengetahuan cukup sebanyak 12 responden (40\%), baik dan kurang masing-masing 2 responden $(6,67 \%)$, sedangkan yang bekerja sebanyak 14 responden $(46,66 \%)$ dengan tingkat pengetahuan cukup sebanyak 7 responden $(23,33 \%)$, kurang sebanyak 4 responden $(13,33 \%)$ dan baik sebanyak 3 responden $(10 \%)$.

Tabel 5 Distribusi Frekuensi Pengetahuan Ibu Tentang Perawatan Kulit Pada Bayi dan Balita Berdasarkan Jumlah Anak.

\begin{tabular}{lcccccccc}
\hline \multirow{3}{*}{ Jumlah anak } & \multicolumn{9}{c}{ Tingkat Pengetahuan } \\
\cline { 2 - 10 } & \multicolumn{3}{c}{ Baik } & \multicolumn{2}{c}{ Cukup } & \multicolumn{2}{c}{ Kurang } & \multicolumn{2}{c}{ Total } \\
\cline { 2 - 10 } & $f$ & & $f$ & $\%$ & $f$ & $\%$ & $f$ & $\%$ \\
\hline Primipara & 1 & 3,33 & 5 & 16,67 & 3 & 10 & 9 & 30 \\
Sekundipara & 3 & 10 & 11 & 36,67 & 2 & 6,67 & 16 & 53,34 \\
Multipara & 1 & 3,33 & 3 & 10 & 1 & 3,33 & 5 & 16,67 \\
Jumlah & 5 & 16,66 & 19 & 63,34 & 6 & 19,99 & 30 & 100 \\
\hline
\end{tabular}

Berdasarkan tabel di atas dapat diketahui bahwa mayoritas responden adalah sekundipara sebanyak 16 responden $(53,34 \%)$ dengan tingkat pengetahuan cukup sebanyak 11 responden $(36,67 \%)$, kurang sebanyak 3 responden $(10 \%)$, dan baik ada 1 responden $(3,33 \%)$. Primipara sebanyak 9 responden $(30 \%)$ dengan tingkat pengetahuan cukup sebanyak 5 responden (16,67\%), kurang sebanyak 3 responden $(10 \%)$ dan baik ada 1 responden (3,33\%). Sedangkan multipara sebanyak 5 responden $(16,67 \%)$ dengan tingkat pengetahuan cukup sebanyak 3 responden (10\%), baik dan kurang ada 1 responden $(3,33 \%)$. 
Tabel 6 Distribusi Frekuensi Variabel Pengetahuan Ibu Tentang Perawatan Kulit Pada Bayi dan Balita yang Meliputi Pengertian, Macam-Macam, Penyebab dan Cara Pengobatan Penyakit Kulit Pada Bayi Dan Balita

\begin{tabular}{|c|c|c|c|c|c|c|c|c|}
\hline \multirow{3}{*}{ Item Pertanyaan } & \multicolumn{8}{|c|}{ Tingkat Pengetahuan } \\
\hline & \multicolumn{2}{|c|}{ Baik } & \multicolumn{2}{|c|}{ Cukup } & \multicolumn{2}{|c|}{ Kurang } & \multicolumn{2}{|c|}{ Total } \\
\hline & $f$ & $\%$ & $f$ & $\%$ & $f$ & $\%$ & $f$ & $\%$ \\
\hline Pengertian & 6 & 20 & 18 & 60 & 6 & 20 & 30 & 100 \\
\hline Macam-macam & 1 & 3,33 & 25 & 83,33 & 4 & 13,83 & 30 & 100 \\
\hline $\begin{array}{l}\text { Penyebab dan Cara } \\
\text { Pengobatan }\end{array}$ & 9 & 30 & 13 & 43,33 & 8 & 26,67 & 30 & 100 \\
\hline
\end{tabular}

Berdasarkan tabel 6 dapat diketahui bahwa tingkat pengetahuan ibu tentang perawatan kulit pada bayi dan balita yang mempunyai pengetahuan berdasarkan pengertian penyakit kulit mayoritas dalam kategori cukup yaitu sebanyak 18 responden (60\%), dan masing-masing 6 responden $(20 \%)$ dalam kategori baik dan kurang. Berdasarkan macam-macam penyakit kulit mayoritas dalam kategori cukup yaitu ada 25 responden $(83,33 \%), 4$ responden $(13,83 \%)$ dalam kategori kurang dan 1 responden $(3,33 \%)$ dalam kategori baik. Pada penyebab dan cara pengobatan penyakit kulit dapat diketahui bahwa pengetahuan ibu mayoritas dalam ketegori cukup yaitu sebanyak 13 responden (43,33\%), 9 responden (30\%) dalam kategori baik dan 8 responden $(26,67 \%)$ dalam kategori kurang.

Dari hasil penelitian tingkat pengetahuan ibu tentang perawatan kulit pada bayi dan balita mayoritas didapatkan 19 respoden $(63,33 \%)$ dengan tingkat pengetahuan dalam kategori cukup yang menunjukkan bahwa mayoritas ibu di Desa Gonilan sudah cukup mendapatkan informasi dan pengetahuan tentang perawatan kulit pada bayi dan balita. Informasi tersebut dapat diperoleh melalui buku, majalah, TV dan radio. Hal ini mendukung teori yang dikemukakan oleh Notoatmodjo (2012) pengetahuan merupakan hasil dari tahu dan ini terjadi setelah seseorang melakukan penginderaan terhadap suatu obyek tertentu. Faktor-faktor yang mempengaruhi pengetahuan antara lain pendidikan, informasi, budaya dan pengalaman (Notoatmodjo, 2012).

Dari hasil penelitian mayoritas umur responden berada pada kelompok usia 25-29 tahun yaitu sejumlah 11 responden $(36,67 \%)$ dengan pengetahuan dalam kategori cukup sebanyak 8 responden $(26,67 \%)$ dan dalam kategori baik sebanyak 2 responden $(6,67 \%)$ dan kurang ada 1 responden $(3,33 \%)$. Hal ini menunjukkan bahwa umur ibu akan mempengaruhi tingkat pengetahuan, semakin dewasa usia seseorang semakin baik pengetahuannya tentang perawatan kulit pada bayi dan balita. Umur menunjukkan kematangan, emosional seseorang dan sejalan dengan kematangan menerima informasi. Pada usia yang lebih tua akan semakin banyak pengalaman yang didapat, sehingga diharapkan dengan semakin banyaknya pengalaman yang didapat oleh seseorang maka pengetahuan tentang perawatan kulit pada bayi dan balita akan semakin banyak.

Hal ini sesuai dengan pendapat Notoatmodjo (2012) yang menyatakan bahwa pencapaian pada tahap tahu dipengaruhi oleh umur dan pengalaman, dimana semakin banyak yang didapat, selain itu juga dipengaruhi oleh media 
cetak, media elektronik, keluarga dan sumber informasi lainya. Pada Ibu yang lebih dewasa umurnya maka kemungkinan pengaruhnya akan menjadi lebih baik. Ibu bisa mendapatkan pengetahuan tentang perawatan kulit pada bayi dan balita dari pengalamannya membaca buku-buku, majalah, TV, Radio. Informasi yang diberikan oleh tenaga kesehatan atau ibu cenderung lebih tahu dan meniru dari pengalaman orang lain maupun pengalaman sendiri.

Dilihat dari tingkat pendidikan responden berasal dari pendidikan terakhir mayoritas adalah SMP sebanyak 10 responden $(33,33 \%)$ dengan tingkat pengetahuan cukup sebanyak 8 responden $(26,67 \%)$, baik dan kurang sebanyak 1 responden $(3,33 \%)$ dari 30 responden yang diteliti. Hal ini dikarenakan pada responden dengan tingkat pendidikan SMP sudah cukup mampu untuk mengembangkan kemampuan yang dimiliki, sehingga dia akan memperoleh pengetahuan yang baru. Hal tersebut mendukung teori Notoatmodjo (2012) bahwa pendidikan adalah suatu kegiatan atau proses pembelajaran untuk mengembangkan atau meningkatkan kemampuan tertentu sehingga sasaran pendidikan itu dapat berdiri sendiri. Sejalan dengan hasil penelitian Heni (2017) yang menunjukan bahwa respondent yang berpendidikan tinggi memiliki pengetahuan yang lebih baik daripada respondent dengan pendidikan yang lebih rendah.

Dari hasil penelitian dapat diketahui bahwa berdasarkan karakteristik pekerjaan mayoritas responden adalah tidak bekerja sebanyak 16 responden $(53,33 \%)$ dengan pengetahuan dalam kategori cukup. Hasil penelitian ini menunjukkan bahwa ibu tidak bekerja mempunyai waktu luang yang banyak untuk mencari informasi baik melalui media cetak maupun media elektronik seperti TV, radio, surat kabar.

Dilihat dari jumlah anak mayoritas responden adalah sekundipara yaitu sebanyak 16 responden $(53,34 \%)$ dengan tingkat pengetahuan cukup. Jumlah anak dapat berpengaruh terhadap pengetahuan dan dengan semakin meningkatnya kemajuan teknologi dan informasi memungkinkan setiap individu mendapatkan informasi dari manapun tanpa batas. Hal tersebut sesuai dengan pendapat Notoatmodjo (2012) yang menyatakan bahwa pengetahuan dipengaruhi oleh beberapa faktor diantaranya oleh pengalaman yang diperoleh seseorang. Pengalaman dapat diperoleh dari pengalaman sendiri maupun orang lain. Pengalaman yang diperoleh dapat memperluas pengetahuan seseorang tentang perawatan kulit pada bayi dan balita.

Dari hasil penelitian dapat diketahui bahwa tingkat pengetahuan ibu tentang pengertian, macam-macam, penyebab dan cara pengobatan penyakit kulit diperoleh bahwa mayoritas ibu memiliki pengetahuan dengan kategori cukup pada item pertanyaan macam-macam penyakit kulit yaitu sebanyak 24 responden $(80 \%)$. Kebanyakan responden mengalami kesulitan dalam menjawab pertanyaan nomor 17 yaitu Hepatitis B, influensa adalah penyebab biduran yang dikarenakan oleh virus. Untuk pengetahuan kategori baik paling banyak pada item pertanyaan penyebab dan cara pengobatan penyakit kulit yaitu sebanyak 9 responden (30\%). Sedangkan untuk pengetahuan kategori kurang paling banyak pada item pertanyaan penyebab dan cara pengobatan yaitu sebanyak 8 responden $(26,67 \%)$. 
Kebanyakan responden mengalami kesulitan dalam menjawab pertanyaan nomor 26 yaitu cara penanganan biang keringat yang sudah menjadi luka pada kepala dengan mencuci rambut dengan menggunakan sampo bayi yang mengandung belerang. Hal ini menunjukkan bahwa sebagian besar responden cukup paham mengenai macam-macam penyakit kulit karena responden telah memperoleh pengetahuan dengan mendengar atau melihat sendiri, serta melalui media komunikasi seperti Radio, TV dan membaca buku.

Untuk pengetahuan kategori kurang terdapat pada item pengobatan dan cara pengobatan penyakit kulit yaitu sebanyak 8 orang $(26,67 \%)$ dikarenakan responden memiliki tingkat pendidikan terakhir SMP sehingga dapat dikatakan pendidikan mereka masih rendah. Hal ini akan berakibat pada tingkat kemampuan responden dalam menggali informasi tentang penyebab dan cara pengobatan penyakit kulit. Hal ini sesuai dengan pendapat Notoatmodjo (2012) bahwa pengetahuan dapat diperoleh melalui pendidikan, karena pendidikan yang cukup tinggi terjadi proses pertumbuhan perkembangan atau perubahan ke arah yang lebih baik dan matang pada individu.

\section{SIMPULAN DAN SARAN}

\section{Simpulan}

Tingkat pengetahuan ibu tentang perawatan kulit pada bayi dan balita di RW VIII Desa Gonilan mayoritas mempunyai pengetahuan cukup yaitu sebanyak 19 responden $(63,33 \%)$ dari 30 responden yang diteliti. Berdasarkan karakteristik umur mayoritas responden berumur 25-29 tahun sebanyak 11 responden $(36,67 \%)$ dengan pengetahuan dalam kategori cukup 8 responden $(26,67 \%)$, berdasarkan pendidikan mayoritas responden berpendidikan terakhir SMP yaitu sebanyak 10 responden $(33,33 \%)$ dengan tingkat pengetahuan cukup 7 responden $(23,33 \%)$, berdasarkan pekerjaan mayoritas responden adalah tidak bekerja yaitu sebanyak 16 responden $(53,34 \%)$ dengan pengetahuan dalam kategori cukup 12 responden (40\%), berdasarkan jumlah anak mayoritas responden adalah sekundipara yaitu sebanyak 16 responden $(53,34 \%)$ dengan pengetahuan cukup 14 responden $(46,67 \%)$.

Tingkat pengetahuan responden tentang perawatan kulit di Desa Gonilan berdasarkan sub variabel pengertian penyakit kulit adalah dalam kategori yaitu cukup sebanyak 18 responden (60\%), tentang macam-macam penyakit kulit adalah dalam kategori cukup yaitu sebanyak 25 responden $(83,33 \%)$, tentang penyebab dan cara pengobatan penyakit kulit adalah dalam kategori cukup yaitu sebanyak 13 responden $(43,33 \%)$.

\section{Saran}

Bagi masyarakat hendaknya dapat meningkatkan pengetahuan baik dengan media cetak atau media elektronik untuk menambah informasi yang didapatkannya tentang pengetahuan kesehatan khususnya ibu yang mempunyai bayi dan balita. Sebagai tenaga kesehatan hendaknya selalu berperan aktif memberikan informasi dan penyuluhan. Diharapkan dari instansi kesehatan 
wilayah penelitian seperti Puskesmas mengadakan program penyuluhan yang mengarah pada pengetahuan tentang perawatan kulit.

\section{DAFTAR PUSTAKA}

Hegab, D.S. 2015. Scabies among primary schoolchildren in Egypt. cameroon: sociomedical environmental study in Kafr El-Sheikh administrative area.

Heni Yuliani. 2017. Hubungan Pengetahuan Ibu tentang Pelaksanaan BBLR dengan Perilaku Ibu dalam Perawatan BBLR di RSUD Wates Yogyakarta. Repository. Unjaya, ac.id/2335 .

Kementerian Kesehatan RI. 2016. INFODATIN Pusat Data dan Informasi Kementerian Kesehatan RI Situasi Balita Pendek. Jakarta Selatan.

Luvilla B , Widyawati , Armalina D. Hubungan Pengetahuan Dan Perilaku Ibu Dengan Kejadian Biang Keringat Pada Bayi Dan Batita. Jurnal Kedokteran Diponegoro. Volume 8, Nomor 3, Juli 2019.

Manulang, Yessi. 2010. Gambaran Pengetahuan Dan Tindakan Ibu Dalam Perawatan Daerah Perianal Terhadap Pencegahan Ruam Popok. http://repository.usu.ac.id/handle/123456789/18663/tanggal akses 7 Juli 2020.

Notoatmodjo S. 2012. Promosi Kesehatan dan Perilaku Kesehatan. Jakarta: PT Rineka Cipta.

Nurfadilah S, Andi Z, Ansariadi. 2014. Faktor Yang Berhubungan Dengan Kejadian Dermatitis Pada Anak Balita Di Wilayah Kerja Pkm Pattopakang Kecamatan Mangarabombang Kabupaten Takalar. http://repository.unhas.ac.id/handle/123456789/9645 / tanggal akses 8 Juni 2020.

Nurhayati dan Maryam. 2013. Pengetahuan Dan Kemampuan Ibu Dalam Perawatan Daerah Perianal Pada Bayi Usia 0-12 Bulan Di Desa Surokonto Wetan Kecamatan Pageruyung Kabupaten Kendal. Jurnal Keperawatan Anak Vol.1 No.1. Mei 2013 (37-43).

Staab D, Kaufmann R, Brautigam M, Wahn U. Treatment of infants with atopic eczema with pimecrolimus cream 1\% improves parents' quality life: A multicenter, randomized trial. Ped Aller Immunol 2015;16:527-33

Sudilarsih, Feni. 2010. Optimal Mengurus Segala Kebutuhan Dan Masalah Bayi Sehari-Hari Anda. Garailmu: Jogjakarta. 